\title{
HPV Transforming Protein E7 Antibody
}

National Cancer Institute

\section{Source}

National Cancer Institute. HPV Transforming Protein E7 Antibody. NCI Thesaurus. Code C129668.

Any immunog lobulin that recognizes HPV transforming protein E7. 